\title{
Anti-Fibrotic Effects of Curcumin and Some of its Analogues in the Heart
}

\section{Armita Mahdavi Gorabi; Saeideh Hajighasemi; Nasim Kiaie; Giuseppe M. C. Rosano; Thozhukat Sathyapalan; Khalid Al-Rasadi; Amirhossein Sahebkar}

\begin{abstract}
Cardiac fibrosis stems from the changes in the expression of fibrotic genes in cardiac fibroblasts (CFs) in response to the tissue damage induced by various cardiovascular diseases (CVDs) leading to their transformation into active myofibroblasts, which produce high amounts of extracellular matrix (ECM) proteins leading, in turn, to excessive deposition of ECM in cardiac tissue. The excessive accumulation of ECM elements causes heart stiffness, tissue scarring, electrical conduction disruption and finally cardiac dysfunction and heart failure. Curcumin (Cur; also known as diferuloylmethane) is a polyphenol compound extracted from rhizomes of Curcuma longa with an influence on an extensive spectrum of biological phenomena including cell proliferation, differentiation, inflammation, pathogenesis, chemoprevention, apoptosis, angiogenesis and cardiac pathological changes. Cumulative evidence has suggested a beneficial role for Cur in improving disrupted cardiac function developed by cardiac fibrosis by establishing a balance between degradation and synthesis of ECM components. There are various molecular mechanisms contributing to the development of cardiac fibrosis. We presented a review of Cur effects on cardiac fibrosis and the discovered underlying mechanisms by them Cur interacts to establish its cardio-protective effects.
\end{abstract}

Keywords: Curcumin; Diferuloylmethane; Theracurmin; C66; J19; Cardiac Fibrosis 
This is a post-peer-review, pre-copyedit version of an article published in Heart Failure Reviews. The final authenticated version is available online at: https://doi.org/10.1007/s10741-019-09854-6.

\section{Introduction}

Cardiac fibrosis is an outcome of a diverse range of conditions including diabetes and cardiovascular diseases (CVDs) resulting in fibrosis of heart and thereby heart failure. In these conditions, fibrosis is primarily aimed to correct the maladaptive developed injury [1,2]. Cardiac fibrosis stems from the expression of fibrotic genes leading to macrophage-mediated transdifferentiation of cardiac fibroblasts (CFs) into active myofibroblasts responsible for secreting proteins involved in contraction such as $\alpha$-smooth muscle actin ( $\alpha$-SMA) and extracellular matrix (ECM) proteins like collagen and elastin [3-5]. In cardiac tissue, ECM is responsible for supporting the cardiac cells' alignment within the tissue to have efficient coupling with other cells nearby throughout the contraction. Normally, the synthesis and degradation procedures relating to ECM components are highly regulated to keep a balance. In case of conditions such as destruction caused by myocardial infarction (MI), the balance between ECM synthesis and degradation is disrupted to compensate for the damage resulting in excessive ECM accumulation [6,7]. The excessive deposition of ECM in cardiac tissue (cardiac fibrosis) is detrimental by itself causing heart stiffness, electrical conduction disruption, development of tissue scars containing high amounts of collagen, left ventricular hypertrophy and ultimately cardiac dysfunction and heart failure [3]. Although different treatments including angiotensin converting enzyme (ACE) inhibitors and angiotensin II receptor blockers have been proposed for the treatment of cardiac fibrosis none of them has been proven effective, especially in heart failure where the incidence of fibrosis is high [8]. Hence, there is an unmet need to find novel strategies against the development and progression of cardiac damage mediated by fibrosis resulting from CVDs.

Curcumin (Cur), also known as diferuloylmethane, is a polyphenolic compound derived from Curcuma longa plant rhizome and the main curcuminoid in the Indian spice, turmeric. This 
This is a post-peer-review, pre-copyedit version of an article published in Heart Failure Reviews. The final authenticated version is available online at: https://doi.org/10.1007/s10741-019-09854-6.

phytochemical has been revealed to exhibit different functions in living systems comprising antithrombotic, anti-inflammatory, anti-oxidant, anti-proliferative, anti-angiogenic and pro-apoptotic, making it or some of its active substances potential therapeutic agents for selected CVDs [9,10]. The remedial use of this compound goes back to traditional medicine in China and India [11]. Cumulative evidence has suggested curcumin to play a positive role in protection against cardiac fibrosis through modulating different molecular pathways via acting on a variety of cytokines, growth factors, and their relating receptors, transcription factors especially those involved in the regulation of cell proliferation, and enzymes [12,13,11].

\section{Molecular mechanisms underlying cardiac fibrosis development}

A fibrotic response is the consequence of a change in expression of genes encoding molecules activating various signaling pathways, including growth factors, cytokines and chemokines that are triggered by internal or external stressors. Some of the most important molecules involved in the process of CF differentiation into myofibroblast and their migration include transforming growth factor $\beta$ (TGF- $\beta$ ), angiotensin II (AngII), platelet-derived growth factor (PDGF)-D, connective tissue growth factor (CTGF), endothelin-1 and interleukin-18 (IL-18) [14-16]. Figure 1 highlights some of the fibrosis mediators and their role in differentiating fibroblasts into myofibroblasts.

Over-expression of AngII activates the Ang II type 1 (AT1) receptor giving rise to cardiac fibrosis by inducing CF proliferation and migration, elevated level of myocardial apoptosis and excessive accumulation of collagen type I (Col I), collagen type III (Col III) and fibronectin (FN) ECM elements [17-20]. In the presence of Ang II, plasminogen activator inhibitor (PAI)-1 is overexpressed in cardiac fibroblasts and the myocardium resulting in an increment in ECM synthesis by fibroblasts, decrement in ECM degradation and metalloproteinase inhibition [21,22]. 
This is a post-peer-review, pre-copyedit version of an article published in Heart Failure Reviews. The final authenticated version is available online at: https://doi.org/10.1007/s10741-019-09854-6.

Transforming growth factor $\beta 1$ (TGF- $\beta 1)$ is another molecule involved in triggering fibrosis and hypertrophy [23][24]. This fibrotic activity of TGF- $\beta 1$ seems to be modulated by acetyltransferase (HAT) activity of transcriptional co-regulator of p300 via the mediation of Smad, leading to enhanced collagen production and fibrotic response initiation [25].

Several in vivo studies demonstrated that the expression of connective tissue growth factor (CTGF) expression is increased in arteries and left ventricle of patients with atherosclerosis and hypertension suggesting both the vascular and cardiac fibrosis are amplified as a consequence of CF and induction of vascular smooth muscle cell proliferation [26,27].

Peroxisome proliferator-activated receptor- $\gamma$ (PPAR- $\gamma$ or NR1C3) is another molecule involved in the development of cardiac fibrosis [28]. Once PPAR- $\gamma$ turns into its activated form as a result of binding to its relevant ligand, it is able to form a heterodimer with retinoid X receptor (RXR) and bind the DNA through PPAR-responsive regulatory elements to regulate the expression of a variety of genes involved in a wide range of biological activities [29]. More specifically, PPAR- $\gamma$ regulates fibrotic and hypertrophic processes in cardiovascular apparatus in response to stress signals [30].

The family of serine/threonine protein kinases C (PKC) encompasses different isozymes. Their activity is associated with pathogenic cardiac issues, including cardiac fibrosis [31]. The activation of a PKC is triggered in response to an extracellular signal activating phospholipase C (PLC) leading to the formation of diacylglycerol (DAG) and inositoltriphosphate (IP3) elevating the intracellular $\mathrm{ca}^{2+}$ content. The PKC is then activated in response to high $\mathrm{ca}^{2+}$ level in the cytosol by binding to DAG located in membrane inducing several downstream signaling pathways such as mitogen-activated protein kinase (MAPK) pathway contributing in a range of different intracellular effects involving modulating cell growth and proliferation [32,33]. Various in vitro 
This is a post-peer-review, pre-copyedit version of an article published in Heart Failure Reviews. The final authenticated version is available online at: https://doi.org/10.1007/s10741-019-09854-6.

and in vivo investigations suggest that in certain conditions such as high amounts of glucose (hyperglycemia) or free fatty acid (FFA) in the bloodstream, the production of DAG increase with associated pathological changes in the cardiac muscles [31,34]. The regulatory effects of PKCs on matrix metalloproteinase (MMP) quantity and function have also been proven to be evident as they enhance the activity of MMP-2 and MMP-9 via MAPK and MMP-9 through JNK signal transduction pathways [34].

In case of exposure to a stress signal like hypertension-induced pressure overload, it has been shown that fibrogenic gene expression is stimulated by the activity of sequence-specific DNA binding transcription factors comprising SMAD2/3, serum response factor (SRF), myocardinrelated transcription factors (MRTFs) and nuclear factor of activated T cells (NFAT) [35].

\section{Mechanisms of curcumin effect on cardiac fibrosis}

Curcumin (Cur), is a natural polyphenol found in turmeric and is derived from Curcuma longa. The potential pharmacological and therapeutic effects of Cur have been studied extensively in a wide range of conditions [36-38]. It has pleiotropic effects in a variety of cells including cardiac cells. Given its hydrophobic nature, presence of a $\beta$-diketone moiety and active methylene group Cur is metabolized in the liver via aldo-keto reductase and has poor bioavailability [39,40]. To circumvent these various modified forms of native curcumin [41-44] as well as its synthetic analogs [45] and derivatives [46] have been used in various studies. The Cur derivatives and analogues which have potential anti-fibrotic effects on heart are (2E,6E)-2,6-bis(2(trifluoromethyl)benzylidene) cyclohexanone, also known as C66 [47], J17 [(2E,5E)-2-(3Hydroxy-4-methoxybenzylidene)-5- (2 nitrobenzylidene) cyclopentanone][48] and tetrahydrocurcumin (THC) [49]. In the following section, we have reviewed various effects of Cur and its metabolites on cardiac fibrosis and potential molecular mechanisms. 
This is a post-peer-review, pre-copyedit version of an article published in Heart Failure Reviews. The final authenticated version is available online at: https://doi.org/10.1007/s10741-019-09854-6.

\section{Inhibition of MMPs expression}

It has been shown that Cur restored the reduced expression of MMP-2 and MMP-9 after HF induction in New Zealand rabbits. Also, the high level of collagen accumulation was reduced in Cur-subjected animals suggesting an anti-fibrotic activity for this compound [50].

\section{TGF- $\beta$ suppression}

Cur reversed changes resulted from TGF- $\beta$ treatment by suppressing the augmented expression of PAI-1 protein in human liver-derived HepG2 cells [51]. In this study, Cur was able to exert almost the same effects as simvastatin, a lipid-lowering medication [51]. In neonatal SD rat CFs reported that Cur administration blocks the pro-fibrotic activity of TGF- $\beta 1$ through reduction of $\alpha$-SMA and Col I at both mRNA and protein levels and suppression of Smad2 and p38 MAPK activation levels [52].

A recent investigation on TGF- $\beta 1$ stimulated human CFs pre-treated with Cur [12] showed a dramatic reduction of $\alpha$-smooth muscle actin ( $\alpha$-SMA), collagen type I $\alpha$ (COLA)-1 and COLA3 expression. Cur was also able to suppress CF proliferation following TGF- $\beta 1$ treatment and stimulate G2/M phase cell cycle arrest. Cur exposure inhibited Smad2/3, p38 MAPK and ERK phosphorylation and consequently down-regulated the expression of cell cycle protein. Conversely, CFs incubated only with Cur did not exhibit any of these changes and the outcomes were consistent with the anti-proliferative and anti-collagen accumulation activities of Cur activities through TGF- $\beta 1$ pathway [12].

Cur dramatically reduced the excessive accumulation of collagen, the expression of TGF- $\beta$ and CTGF pro-fibrotic genes as well as the protein levels of collagen I and matrix metalloproteinase9 (MMP-9) in Cur-treated C57BL/6 mice fed on a high-fat diet (HFD) [53]. This suggests that Cur neutralizes the adverse effects of HFD on the cardiac tissue [53]. Furthermore, curcumin pre- 
This is a post-peer-review, pre-copyedit version of an article published in Heart Failure Reviews. The final authenticated version is available online at: https://doi.org/10.1007/s10741-019-09854-6.

exposure of H9c2 embryonic rat heart-derived cells followed by treatment with palmitate (PA) resulted in a reversal of hypertrophy induced by PA [53]. The PA-stimulated high expression level of TGF- $\beta$ was shown to be down-regulated in cells pre-treated with Cur [53].

\section{Altering MAPK phosphorylation}

Soetikno, and colleagues [54] assessed the cardio-protective effect of curcumin in high glucose (HG)-related cardiomyopathy in SD rats by streptozotocin (STZ) injection. As a result of the induction of diabetes, the PKC- $\alpha$ and $-\beta 2$ isozymes were translocated to the membrane as an indication of their activation, which was inhibited following Cur treatment. The increased amount of phosphorylated p38MAPK and ERK1/2 in diabetic animals-related tissue samples from left ventricle was reduced by following treatment with Cur [54]. The expression of TGF- $\beta$, osteopontin and p300 transcriptional coactivator as an indicative of anti-fibrotic Cur activity was decreased which was shown by reduced ECM deposition and shrinkage of fibrotic areas [54].

In another study diabetes was induced in SD rats by feeding them on a high energy diet and a lowdose streptozotocin (STZ) injection [55]. Heart specimens from Cur-treated diabetic rats exhibited lower collagen type I and III accumulation compared to Cur-untreated animals. Additionally, TGF$\beta 1$, T $\beta$ R II and phosphorylated Smad 2/3 were detected only at remarkably low levels. However, the expression of Smad 7 was enhanced in those rats [55]. When human CFs were subjected to Cur, accompanied by high glucose (HG) or treatment with TGF- $\beta 1$. The over-activity of AMPK/p38 MAPK stimulated by HG or TGF- $\beta 1$ was found to be suppressed and the collagen synthesis was attenuated in those cells as a result of Cur treatment [55].

\section{Suppression of Smads phosphorylation}

Bugyei-Twum et al. pre-treated H9c2 rat cardiomyoblast cells using $25 \mu \mathrm{M}$ Cur followed by HG administration. The Cur pre-treatment led to inhibition of the HG-stimulated p300 activity. When 
This is a post-peer-review, pre-copyedit version of an article published in Heart Failure Reviews. The final authenticated version is available online at: https://doi.org/10.1007/s10741-019-09854-6.

neonatal rat fibroblasts were treated with Cur there was a significant reduction in collagen synthesis confirming its counter-HG/ TGF- $\beta$ behavior [56]. Cur also reduced the level of acetylated Smad2 in TGF- $\beta$-stimulated H9c2 cardiomyoblasts. The up-regulated Smad7 mRNA, induced by treatments with HG or TGF- $\beta$, was suppressed by Cur both in vitro and in vivo. The Cur-treated diabetic Ren-2 rats showed a reduced amount of hypertrophy in heart, ECM synthesis and restoration of diastolic function [56].

The cardiac fibroblasts isolated from Sprague-Dawley (SD) rats were treated with Cur along with TGF- $\beta 1$ or Ang II [57]. It was found that Cur enhanced the activity of matrix metalloproteinase (MMP)-2 and diminished the levels of the phosphorylated extracellular signal-regulated kinase (ERK) $1 / 2$ in the presence of Ang II. Analyzing CFs co-treated with Cur and TGF- $\beta 1$ showed reduced expression levels of phosphorylated Smad2/3 and Akt [57]. This study demonstrated that Cur administration attenuates CF proliferation and migration and keeps their collagen production at baseline level regardless of the presence of TGF- $\beta 1$ or Ang II [57].

\section{Inhibition of toll-like receptor 2 expression}

To gain insight into the cardioprotective effects of Cur after ischemia/reperfusion (I/R) injuries, SD rats were first orally administered with $300 \mathrm{mg} / \mathrm{kg} /$ day Cur for seven days before undergoing I/R injury [58]. The expression of toll-like receptor 2 (TLR2), known to contribute in myocardial infarction, was prominently amplified in the infarct zone of IR rat models; however, the expression of TLR4 showed a constant pattern [58]. The up-regulation of TLR2 was reversed in Cur-treated animals. There was a reduction of macrophage infiltration (CD68) and high mobility group box 1 in Cur-treated IR rat models, whereas, their levels increased in the absence of Cur post the IR injury [58]. Furthermore, comparing changes in neonatal rat-derived myocardial cells stimulated by tumor necrosis factor (TNF)- $\alpha$, peptidoglycan $(\mathrm{PGN})$ or hypoxia/reoxygenation $(\mathrm{H} / \mathrm{R})$ in the 
This is a post-peer-review, pre-copyedit version of an article published in Heart Failure Reviews. The final authenticated version is available online at: https://doi.org/10.1007/s10741-019-09854-6.

presence and absence of $10 \mu \mathrm{M}$ Cur, the inhibitory effect of Cur on over-expressed TLR2 and monocyte chemoattractant protein (MCP)-1 became apparent [58].

\section{Increasing Akt phosphorylation}

Experimental diabetes was induced in Wistar rats via a high-fat diet (HFD) and intraperitoneal (I.P.) injection of STZ [59] followed by administration of Cur. The ratio of fibrosis area to the entire myocardial area in diabetic rats was attenuated by curcumin [59]. Cur declined diabetic cardiomyopathy by promoting protein kinase B (Akt) and GSK-3 $\beta$ phosphorylation [59].

\section{PPAR- $\gamma$ activation}

In spontaneously hypertensive rats (SHRs) Cur treatment reduced the Ang II levels in the blood, the ratios of heart weight/body weight and left ventricle weight/body weight, systolic blood pressure and the expression levels of CTGF, PAI-1, Col III, and FN [13]. There was also upregulation of A PPAR- $\gamma$ after Cur treatment. Left ventricle samples showed a reduction of collagen accumulation after daily oral treatment of Cur. In groups concomitantly treated with Cur and GW9f662 (PPAR- $\gamma$ antagonist), the anti-fibrotic activity of curcumin was overturned (Figure

2) [13]. Pretreatment of cardiac fibroblasts with Cur suppressed the Ang II-promoted expression of CTGF, PAI-1, collagen III (Col III/COLA-3), FN, TGF- $\beta 1$ and also inhibited phosphorylation of Smad2/3. It also increased the PPAR- $\gamma$ expression and binding capability in a dose-dependent manner. GW9662 pre-treatment, on the other hand, exerted negative effects on Cur-induced antifibrotic activities [13] suggesting that Cur can suppress the cardiac fibrosis in SHRs via modulating PPAR- $\gamma$ and TGF- $\beta 1 /$ Smad2/3 signaling interaction [13]. 
This is a post-peer-review, pre-copyedit version of an article published in Heart Failure Reviews. The final authenticated version is available online at: https://doi.org/10.1007/s10741-019-09854-6.

When SD rats after left coronary artery ligation were exposed to Cur [60] there was notable shrinkage of the fibrosis area due to myocardial infarction (MI) after oral treatment of Cur in a dose-dependent manner [60].

\section{Affecting angiotensin receptors expression}

Ang II-perfused Sprague Dawley (SD) rats were used to investigate the anti-fibrotic effect of dietary Cur post-Ang II infusion [61]. Cur was found reduce the fibrosis in the intra-cardiac vessels and myocardium by dramatic suppression of AT1 receptor expression after four weeks and, inversely, up-regulation of AT2 receptor expression enhancing through time suggesting dual effects of Cur on AT1 and AT2 receptors [61]. The elevated numbers of macrophages and alphaSMA-expressing myofibroblasts accumulated in specimens from Ang II-injected rats was significantly decreased following administration of dietary Cur over 28 days [61]. Cur treatment also down-regulated the expression of TGF- $\beta 1$ and phosphorylated-Smad2/3, suppressed the synthesis of collagen I and reduced the collagen-rich areas [61]. Finally, the reduced ACE2 levels after Ang II injection was abrogated by Cur intake [61].

\section{Reducing inflammation}

An in vivo study after intraperitoneal (I.P.) injection of Cur on hind limb ischemia mouse model revealed amelioration of cardiac fibrosis damages occurred by ischemia [62]. This study demonstrated that Cur-induced cardio-protective outcomes are mediated by inhibition of NF-kB activation and macrophage infiltration and down-regulation of inflammatory markers (TNF- $\alpha$, IL1 and IL-6) [62,38].

\section{Restoring sirtuin protein 1 inhibition}

Xiao et al. [8], studied the Cur-induced changes in C57BL/6J wild-type male mice about one month after MI induction. Four weeks post-MI induction, the experiments revealed that there was 
This is a post-peer-review, pre-copyedit version of an article published in Heart Failure Reviews. The final authenticated version is available online at: https://doi.org/10.1007/s10741-019-09854-6.

significant shrinkage of interstitial areas affected by fibrosis in Cur-received animals. The expression levels of collagen I, collagen III and TGF- $\beta 1$ were found to be down-regulated. The Cur treatment led to the restoration of post-MI inhibition of sirtuin protein 1 (SIRT1), a histone deacetylase. Cur suppressed the proliferation and migration of Ang II-exposed CFs, decreased the deposition of collagen and down-regulated the expression of matrix metalloproteinase (MMP)-9 and -2 [8]. Furthermore, the siRNA-SIRT1-mediated down-regulation of SIRT1 in Ang IIincubated CFs suggested the involvement of SIRT1 in anti-fibrotic property of Cur [8].

\section{Inhibiting expression of autophagy markers}

Another recent study investigated the contribution of autophagy in anti-fibrotic and antihypertrophic activities of Cur in ISO-induced rat models of cardiac hypertrophy and fibrosis [63]. The heart weight/body weight ratio in Cur-treated hypertrophic rat models decreased by 13.1\% and reversed the ISO-induced expression changes in hypertrophic markers including atrial natriuretic peptide (ANP), $\alpha$-myosin heavy chain ( $\alpha$-MHC or MYH6), $\beta$-MHC (MYH7) and MYH7B [63]. The extent of interstitial fibrosis area formed following ISO exposure was limited by Cur intervention. The expression of genes encoding fibrotic markers of procollagen I and procollagen III, which were increased by ISO, decreased to roughly more than $50 \%$ as a result of treatment with Cur. Although ISO suppressed mTOR expression, treatment with Cur restored mTOR expression. The expression of autophagy markers, including LC3 and Belin-1, was upregulated the presence of ISO, while Cur treatment completely abolished this effect [63].

\section{Cur pharmacokinetics and safety}

Cur is known to have poor bioavailability limiting its application as a therapeutic agent. Its relatively low absorption, rapid metabolism and clearance from the body contribute to its poor bioavailability [64]. The high lipophilic property of Cur contributes to its low solubility in aqueous 
This is a post-peer-review, pre-copyedit version of an article published in Heart Failure Reviews. The final authenticated version is available online at: https://doi.org/10.1007/s10741-019-09854-6.

environments [65]. Cur is poorly absorbed when orally administered (almost undetectable in plasma, liver and brain after $30 \mathrm{~min}$ ), while it is detectable (at low levels) in animals with parenteral administration [66]. Cur is both chemically and metabolically unstable [67]. Once administered in neutral to alkaline environments, Cur rapidly (within $30 \mathrm{~min}$ ) degrades to form mainly bicyclopentadione and autoxidation products, and to a less extent ferulic acid, feruloyl methane and vanillin [68]. In acidic environments, on the other hand, the degradation rate is significantly lower [64].

After oral ingestion, only a low proportion of Cur is absorbed through the intestinal tract which undergoes rapid metabolism in plasma and liver and the rest are excreted in feces [64]. While being metabolized, the absorbed Cur go through two different phases including reduction and conjugation. In the reduction phase, the double bonds are reduced via NADPH-dependent curcumin/dihydrocurcumin reductase. In the next phase, the previously reduced metabolites of Cur and Cur itself undergo $\beta$-glucuronidase/sulfatase enzymes- mediated conjugation with glucuronic acid or sulfuric acid-producing glucuronides and sulfates in the liver. A proportion of these watersoluble products are then excreted into the duodenum via bile, and the rest is released into the blood and excreted through the urine $[64,65]$. Only the free form of Cur is active while the conjugated forms of Cur are inactive and are rapidly eliminated from the body $[65,68]$. Cur is well tolerated and causes no harm even when administered at very high doses [67].

\section{Curcumin analogues and cardiac fibrosis}

In view of the poor bioavailability of Cur after oral administration [69], several studies have been conducted on the evaluation of anti-fibrotic properties of Cur derivatives to address this limitation. Pang and colleagues [47] used (2E,6E)-2,6-bis(2-(trifluoromethyl)benzylidene) cyclohexanone, also known as C66, a synthetic curcumin derivative, in type 1 diabetic mice to validate its 
This is a post-peer-review, pre-copyedit version of an article published in Heart Failure Reviews. The final authenticated version is available online at: https://doi.org/10.1007/s10741-019-09854-6.

cardioprotective potential. The elevated heart weight/body weight ratio was decreased after a twomonth treatment suggesting a beneficial role of C66 in preventing pathological changes in cardiac tissue and potentially reversing diabetic cardiomyopathy [47]. The C66 compound was also used in another study performed on streptozotocin-injected C57BL/6 mice to evaluate its protective effects against diabetic cardiomyopathy [70]. The three-month administration of C66 at a concentration to diabetic mice reduced cardiac fibrosis and cardiac function decrement compared to C66-untreated diabetic mice. The cardioprotective function of C66 was suggested to be due to down-regulation of c-Jun NH2-terminal kinase (JNK) activation [70].

To shed more light on molecular mechanisms behind the cardio-protective action of C66 when diabetic JNK2-/- and wild-type (WT) mouse models were fed with C66 [71] there was a reduction in diabetes-induced cardiac fibrosis due to its inhibitory effect on the JNK2 activity. In contrast to non-treated WT diabetic mice, there was a reduction in expression of TGF- $\beta 1$, CTGF, and PAI- 1 pro-fibrotic factor in C66-treated WT diabetic mice resulting in reduced collagen deposition in the interstitial areas. On the other hand, there were no fibrotic changes in cardiac tissues from JNK2-/mouse models [71].

Since chronic kidney diseases (CKD) are accompanied by CVD-related complications like cardiac fibrosis, a compound called theracurmin with the similar formulation as Cur was fed to CKD SD rat models by gavage [72]. After treatment with theracurmin, both cardiac structure and function improved and cardiac fibrosis and hypertrophy were reduced in rats with CKD. The assessment of expression of pro-fibrotic and pro-hypertrophic genes in heart tissues isolated from the treated rats showed the suppressive effects of theracurmin on TGF- $\beta 1, \beta-\mathrm{MHC}$, and type I collagen. Besides, theracurmin lowered the phosphorylation level of Smad2 [72]. 
This is a post-peer-review, pre-copyedit version of an article published in Heart Failure Reviews. The final authenticated version is available online at: https://doi.org/10.1007/s10741-019-09854-6.

A Cur analog called J17 [(2E,5E)-2-(3-Hydroxy-4-methoxybenzylidene)-5- (2 nitrobenzylidene) cyclopentanone] [48] was tested as a possible Cur alternative to reverse cardiomyopathy and fibrosis established by diabetes. There was a reduction of fibrosis via AKT signal transduction silencing in H9C2 rat myoblast cells cultured in the presence of DMSO-dissolved Cur and J17. These were added thirty minutes before high glucose-mediated fibrosis stimulation. There was a stronger dose-dependent inhibitory activity with J17 compared to the Cur-induced inhibitory effects [48]. Male C57BL/6 mice were subjected to either J17 solubilized in 0.5\% sodium carboxyl methyl cellulose (CMC-Na) at a concentration of $10 \mathrm{mg} / \mathrm{kg}$ or Cur at a concentration of $50 \mathrm{mg} / \mathrm{kg}$ administered by gavage eight days after the induction of diabetes mellitus [48]. The heart tissue sections from which received Cur- and J17 showed a significant attenuation of collagen deposition and cardiac fibrosis. The over-expression of collagen type I and TGF- $\beta$ were attenuated in diabetic mice treated with J17 to physiological level [48]. Similarly, the level of TNF- $\alpha$ and ICAM-1 transcripts in heart specimens were reduced to their relevant normal physiological levels following the administration of J17 [48]. This suggests a protective effect of J17 against fibrosis and other cardiac pathological changes after initiation of a fibrosis response due to diabetic hyperglycemia [48].

When a metabolite of Cur, tetrahydrocurcumin (THC), was orally administered to STZ-induced diabetic mice [49], there was improvement of cardiac function. THC treatment also attenuated fibrosis within myocardium in THC-received diabetic mice by up-regulation of SIRT1 signaling pathway expression. THC treatment was also accompanied by suppression of acetylation and stimulation of deacetylation of SOD2, a SIRT1 downstream molecule reinforcing the antioxidative capacity. The administration of THC inhibited TGF $\beta 1 / \mathrm{Smad} 3$ signaling pathway 
This is a post-peer-review, pre-copyedit version of an article published in Heart Failure Reviews. The final authenticated version is available online at: https://doi.org/10.1007/s10741-019-09854-6.

activated by reactive oxygen species (ROS). The collagen deposition was significantly reduced after THC exposure in the cardiac tissue of diabetic mice [49].

\section{Conclusion}

Mounting evidence, both in vitro and in vivo, support the anti-fibrotic functions of Cur and its analogues in the presence of various pro-fibrotic factors (Table 1). Cur reverses the effect of profibrotic factors through altering the expression and activation of numerous intracellular molecules. These evidences suggest that curcumin and its metabolites could potentially act as an effective adjuvant to inhibit the progression of myocardial damage resulting from various conditions that may lead to heart failure. It can be implied that Cur is a safe herbal medication that merely targets the cells responsible for the disease, while leaving normal ones unaffected. Various measures including the use of altered formulations of Cur, concomitant administration of Cur with agents reducing its metabolism and designing oral delivery systems using structures such as liposomes and nanoparticles are necessary to tackle the low bioavailability of Cur.

\section{Compliance with ethical standards}

Conflict of interest: The authors declare that they have no competing interests.

Ethics approval: Not applicable.

Informed consent: Not applicable.

Date availability: Not applicable.

Acknowledgements: None.

Funding: None. 
This is a post-peer-review, pre-copyedit version of an article published in Heart Failure Reviews. The final authenticated version is available online at: https://doi.org/10.1007/s10741-019-09854-6.

\section{References}

1. Grimaldi V, De Pascale MR, Zullo A, Soricelli A, Infante T, Mancini FP, Napoli C (2017) Evidence of epigenetic tags in cardiac fibrosis. Journal of Cardiology 69 (2):401-408

2. Russo I, Frangogiannis NG (2016) Diabetes-associated cardiac fibrosis: cellular effectors, molecular mechanisms and therapeutic opportunities. Journal of molecular and cellular cardiology 90:84-93

3. Tao H, Shi K-H, Yang J-J, Huang C, Liu L-P, Li J (2013) Epigenetic regulation of cardiac fibrosis. Cellular signalling 25 (9):1932-1938

4. Wang NP, Wang ZF, Tootle S, Philip T, Zhao ZQ (2012) Curcumin promotes cardiac repair and ameliorates cardiac dysfunction following myocardial infarction. British journal of pharmacology 167 (7):1550-1562

5. van Putten S, Shafieyan Y, Hinz B (2016) Mechanical control of cardiac myofibroblasts. Journal of molecular and cellular cardiology 93:133-142

6. Creemers EE, van Rooij E (2016) Function and therapeutic potential of noncoding RNAs in cardiac fibrosis. Circulation research 118 (1):108-118

7. Micheletti R, Plaisance I, Abraham BJ, Sarre A, Ting C-C, Alexanian M, Maric D, Maison D, Nemir M, Young RA (2017) The long noncoding RNA Wisper controls cardiac fibrosis and remodeling. Science translational medicine 9 (395):eaai9118

8. Xiao J, Sheng X, Zhang X, Guo M, Ji X (2016) Curcumin protects against myocardial infarction-induced cardiac fibrosis via SIRT1 activation in vivo and in vitro. Drug design, development and therapy 10:1267

9. Kunnumakkara AB, Bordoloi D, Padmavathi G, Monisha J, Roy NK, Prasad S, Aggarwal BB (2017) Curcumin, the golden nutraceutical: multitargeting for multiple chronic diseases. British journal of pharmacology 174 (11):13251348

10. Mokhtari-Zaer A, Marefati N, Atkin SL, Butler AE, Sahebkar A (2018) The protective role of curcumin in myocardial ischemia-reperfusion injury. J Cell Physiol 234 (1):214-222. doi:10.1002/jcp.26848

11. Wongcharoen W, Phrommintikul A (2009) The protective role of curcumin in cardiovascular diseases. International journal of cardiology 133 (2):145-151

12. Fang G, Chen S, Huang Q, Chen L, Liao D (2018) Curcumin suppresses cardiac fibroblasts activities by regulating the proliferation and cell cycle via the inhibition of the p38 MAPK/ERK signaling pathway. Molecular medicine reports 18 (2):1433-1438 
This is a post-peer-review, pre-copyedit version of an article published in Heart Failure Reviews. The final authenticated version is available online at: https://doi.org/10.1007/s10741-019-09854-6.

13. Meng Z, Yu X-h, Chen J, Li L, Li S (2014) Curcumin attenuates cardiac fibrosis in spontaneously hypertensive rats through PPAR- $\gamma$ activation. Acta Pharmacologica Sinica 35 (10):1247

14. Leask A (2010) Potential therapeutic targets for cardiac fibrosis: TGF $\beta$, angiotensin, endothelin, CCN2, and PDGF, partners in fibroblast activation. Circulation research 106 (11):1675-1680

15. Valente AJ, Sakamuri SS, Siddesha JM, Yoshida T, Gardner JD, Prabhu R, Siebenlist U, Chandrasekar B (2013) TRAF3IP2 mediates interleukin-18-induced cardiac fibroblast migration and differentiation. Cellular signalling 25 (11):2176-2184

16. Zhao T, Zhao W, Chen Y, Li VS, Meng W, Sun Y (2013) Platelet-derived growth factor-D promotes fibrogenesis of cardiac fibroblasts. American Journal of Physiology-Heart and Circulatory Physiology 304 (12):H1719-H1726

17. Shimosawa T (2013) Salt, the renin-angiotensin-aldosterone system and resistant hypertension. Hypertension Research 36 (8):657

18. de Cavanagh EM, Ferder M, Inserra F, Ferder L (2009) Angiotensin II, mitochondria, cytoskeletal, and extracellular matrix connections: an integrating viewpoint. American Journal of Physiology-Heart and Circulatory Physiology 296 (3):H550-H558

19. Siddesha JM, Valente AJ, Sakamuri SS, Yoshida T, Gardner JD, Somanna N, Takahashi C, Noda M, Chandrasekar B (2013) Angiotensin II stimulates cardiac fibroblast migration via the differential regulation of matrixins and RECK. Journal of molecular and cellular cardiology 65:9-18

20. Crowley MJ, Powers BJ, Myers ER, McBroom AJ, Sanders GD (2012) Angiotensin-converting enzyme inhibitors and angiotensin II receptor blockers for treatment of ischemic heart disease: future research needs prioritization. American heart journal 163 (5):777-782. e778

21. Ghosh AK, Vaughan DE (2012) PAI-1 in tissue fibrosis. Journal of cellular physiology 227 (2):493-507

22. Weisberg AD, Albornoz F, Griffin JP, Crandall DL, Elokdah H, Fogo AB, Vaughan DE, Brown NJ (2005) Pharmacological inhibition and genetic deficiency of plasminogen activator inhibitor-1 attenuates angiotensin II/saltinduced aortic remodeling. Arteriosclerosis, thrombosis, and vascular biology 25 (2):365-371

23. Khan R, Sheppard R (2006) Fibrosis in heart disease: understanding the role of transforming growth factor- $\beta 1$ in cardiomyopathy, valvular disease and arrhythmia. Immunology 118 (1):10-24 
This is a post-peer-review, pre-copyedit version of an article published in Heart Failure Reviews. The final authenticated version is available online at: https://doi.org/10.1007/s10741-019-09854-6.

24. Hein S, Arnon E, Kostin S, Schönburg M, Elsässer A, Polyakova V, Bauer EP, Klövekorn W-P, Schaper J (2003) Progression from compensated hypertrophy to failure in the pressure-overloaded human heart: structural deterioration and compensatory mechanisms. Circulation 107 (7):984-991

25. Ghosh AK, Varga J (2007) The transcriptional coactivator and acetyltransferase p300 in fibroblast biology and fibrosis. Journal of cellular physiology 213 (3):663-671

26. Daniels A, Van Bilsen M, Goldschmeding R, Van Der Vusse G, Van Nieuwenhoven F (2009) Connective tissue growth factor and cardiac fibrosis. Acta physiologica 195 (3):321-338

27. Gao D-F, Niu X-L, Hao G-H, Peng N, Wei J, Ning N, Wang N-P (2007) Rosiglitazone inhibits angiotensin IIinduced CTGF expression in vascular smooth muscle cells-Role of PPAR- $\gamma$ in vascular fibrosis. Biochemical pharmacology 73 (2):185-197

28. Derosa G, Maffioli P (2012) Peroxisome proliferator-activated receptor- $\gamma$ (PPAR- $\gamma$ ) agonists on glycemic control, lipid profile and cardiovascular risk. Current Molecular Pharmacology 5 (2):272-281

29. Ahmadian M, Suh JM, Hah N, Liddle C, Atkins AR, Downes M, Evans RM (2013) PPAR $\gamma$ signaling and metabolism: the good, the bad and the future. Nature medicine 19 (5):557

30. Wei W-Y, Zhang N, Li L-L, Ma Z-G, Xu M, Yuan Y-P, Deng W, Tang Q-Z (2018) Pioglitazone alleviates cardiac fibrosis and inhibits endothelial to mesenchymal transition induced by pressure overload. Cellular Physiology and Biochemistry 45 (1):26-36

31. Singh RM, Cummings E, Pantos C, Singh J (2017) Protein kinase C and cardiac dysfunction: a review. Heart failure reviews 22 (6):843-859

32. Huang K-P (1989) The mechanism of protein kinase C activation. Trends in neurosciences 12 (11):425-432

33. Singh RK, Kumar S, Gautam PK, Tomar MS, Verma PK, Singh SP, Acharya A (2017) Protein kinase C- $\alpha$ and the regulation of diverse cell responses. Biomolecular concepts 8 (3-4):143-153

34. Roberts AC, Porter KE (2013) Cellular and molecular mechanisms of endothelial dysfunction in diabetes. Diabetes and Vascular Disease Research 10 (6):472-482

35. Davis J, Molkentin JD (2014) Myofibroblasts: trust your heart and let fate decide. Journal of molecular and cellular cardiology 70:9-18

36. Cicero AFG, Colletti A, Bajraktari G, Descamps O, Djuric DM, Ezhov M, Fras Z, Katsiki N, Langlois M, Latkovskis G, Panagiotakos DB, Paragh G, Mikhailidis DP, Mitchenko O, Paulweber B, Pella D, Pitsavos C, Reiner 
This is a post-peer-review, pre-copyedit version of an article published in Heart Failure Reviews. The final authenticated version is available online at: https://doi.org/10.1007/s10741-019-09854-6.

Z, Ray KK, Rizzo M, Sahebkar A, Serban MC, Sperling LS, Toth PP, Vinereanu D, Vrablík M, Wong ND, Banach M (2017) Lipid-lowering nutraceuticals in clinical practice: Position paper from an International Lipid Expert Panel. Nutrition Reviews 75 (9):731-767. doi:10.1093/nutrit/nux047

37. Panahi Y, Khalili N, Sahebi E, Namazi S, Karimian MS, Majeed M, Sahebkar A (2017) Antioxidant effects of curcuminoids in patients with type 2 diabetes mellitus: a randomized controlled trial. Inflammopharmacology 25 (1):25-31. doi:10.1007/s10787-016-0301-4

38. Sahebkar A, Cicero AFG, Simental-Mendía LE, Aggarwal BB, Gupta SC (2016) Curcumin downregulates human tumor necrosis factor- $\alpha$ levels: A systematic review and meta-analysis ofrandomized controlled trials. Pharmacological Research 107:234-242. doi:https://doi.org/10.1016/j.phrs.2016.03.026

39. Panahi Y, Saadat A, Beiraghdar F, Hosseini Nouzari SM, Jalalian HR, Sahebkar A (2014) Antioxidant effects of bioavailability-enhanced curcuminoids in patients with solid tumors: A randomized double-blind placebo-controlled trial. Journal of Functional Foods 6:615-622. doi:https://doi.org/10.1016/j.jff.2013.12.008

40. Ghasemi F, Bagheri H, Barreto GE, Read MI, Sahebkar A (2019) Effects of Curcumin on Microglial Cells. Neurotoxicity research. doi:10.1007/s12640-019-00030-0

41. Hagl S, Kocher A, Schiborr C, Kolesova N, Frank J, Eckert GP (2015) Curcumin micelles improve mitochondrial function in neuronal PC12 cells and brains of NMRI mice - Impact on bioavailability. Neurochemistry international 89:234-242. doi:10.1016/j.neuint.2015.07.026

42. Sandhir R, Yadav A, Mehrotra A, Sunkaria A, Singh A, Sharma S (2014) Curcumin nanoparticles attenuate neurochemical and neurobehavioral deficits in experimental model of Huntington's disease. Neuromolecular medicine 16 (1):106-118. doi:10.1007/s12017-013-8261-y

43. Chojnacki JE, Liu K, Yan X, Toldo S, Selden T, Estrada M, Rodríguez-Franco MI, Halquist MS, Ye D, Zhang S (2014) Discovery of 5-(4-hydroxyphenyl)-3-oxo-pentanoic acid [2-(5-methoxy-1H-indol-3-yl)-ethyl]-amide as a neuroprotectant for Alzheimer's disease by hybridization of curcumin and melatonin. ACS chemical neuroscience 5 (8):690-699. doi:10.1021/cn500081s

44. Chang CZ, Wu SC, Lin CL, Kwan AL (2015) Curcumin, encapsulated in nano-sized PLGA, down-regulates nuclear factor kappaB (p65) and subarachnoid hemorrhage induced early brain injury in a rat model. Brain research 1608:215-224. doi:10.1016/j.brainres.2015.02.039 
This is a post-peer-review, pre-copyedit version of an article published in Heart Failure Reviews. The final authenticated version is available online at: https://doi.org/10.1007/s10741-019-09854-6.

45. Jayaraj RL, Tamilselvam K, Manivasagam T, Elangovan N (2013) Neuroprotective effect of CNB-001, a novel pyrazole derivative of curcumin on biochemical and apoptotic markers against rotenone-induced SK-N-SH cellular model of Parkinson's disease. Journal of molecular neuroscience : MN 51 (3):863-870. doi:10.1007/s12031-013-00758

46. Mythri RB, Harish G, Dubey SK, Misra K, Bharath MM (2011) Glutamoyl diester of the dietary polyphenol curcumin offers improved protection against peroxynitrite-mediated nitrosative stress and damage of brain mitochondria in vitro: implications for Parkinson's disease. Molecular and cellular biochemistry 347 (1-2):135-143. doi:10.1007/s11010-010-0621-4

47. Pan Y, Wang Y, Zhao Y, Peng K, Li W, Wang Y, Zhang J, Zhou S, Liu Q, Li X (2014) Inhibition of JNK phosphorylation by a novel curcumin analog prevents high glucose-induced inflammation and apoptosis in cardiomyocytes and the development of diabetic cardiomyopathy. Diabetes 63 (10):3497-3511

48. Chen H, Yang X, Lu K, Lu C, Zhao Y, Zheng S, Li J, Huang Z, Huang Y, Zhang Y (2017) Inhibition of high glucose-induced inflammation and fibrosis by a novel curcumin derivative prevents renal and heart injury in diabetic mice. Toxicology letters 278:48-58

49. Li K, Zhai M, Jiang L, Song F, Zhang B, Li J, Li H, Li B, Xia L, Xu L (2019) Tetrahydrocurcumin Ameliorates Diabetic Cardiomyopathy by Attenuating High Glucose-Induced Oxidative Stress and Fibrosis via Activating the SIRT1 Pathway. Oxidative medicine and cellular longevity 2019

50. Tang Y, Bao M, Yang B, Zhang Y, Zhang B, Zhou Q, Chen J, Huang C (2009) Curcumin attenuates left ventricular dysfunction and remodeling in rabbits with chronic heart failure. Zhonghua xin xue guan bing za zhi 37 (3):262-267 51. Nakayama N, Nakamura T, Okada H, Iwaki S, Sobel BE, Fujii S (2011) Modulators of induction of plasminogen activator inhibitor type-1 in HepG2 cells by transforming growth factor- $\beta$. Coronary artery disease 22 (7):468-478 52. Liu H, Liu A, Shi C, Li B (2016) Curcumin suppresses transforming growth factor- $\beta 1$-induced cardiac fibroblast differentiation via inhibition of Smad-2 and p38 MAPK signaling pathways. Experimental and therapeutic medicine 11 (3):998-1004

53. Zeng C, Zhong P, Zhao Y, Kanchana K, Zhang Y, Khan ZA, Chakrabarti S, Wu L, Wang J, Liang G (2015) Curcumin protects hearts from FFA-induced injury by activating Nrf2 and inactivating NF- $\mathrm{BB}$ both in vitro and in vivo. Journal of molecular and cellular cardiology 79:1-12 
This is a post-peer-review, pre-copyedit version of an article published in Heart Failure Reviews. The final authenticated version is available online at: https://doi.org/10.1007/s10741-019-09854-6.

54. Soetikno V, Sari FR, Sukumaran V, Lakshmanan AP, Mito S, Harima M, Thandavarayan RA, Suzuki K, Nagata M, Takagi R (2012) Curcumin prevents diabetic cardiomyopathy in streptozotocin-induced diabetic rats: possible involvement of PKC-MAPK signaling pathway. European Journal of Pharmaceutical Sciences 47 (3):604-614

55. Guo S, Meng X-w, Yang X-s, Liu X-f, Ou-Yang C-h, Liu C (2018) Curcumin administration suppresses collagen synthesis in the hearts of rats with experimental diabetes. Acta Pharmacologica Sinica 39 (2):195

56. Bugyei-Twum A, Advani A, Advani SL, Zhang Y, Thai K, Kelly DJ, Connelly KA (2014) High glucose induces Smad activation via the transcriptional coregulator p300 and contributes to cardiac fibrosis and hypertrophy. Cardiovascular diabetology 13 (1):89

57. Chung C-C, Kao Y-H, Liou J-P, Chen Y-J (2014) Curcumin suppress cardiac fibroblasts activities by regulating proliferation, migration, and the extracellular matrix. Acta Cardiologica Sinica 30 (5):474

58. Kim YS, Kwon JS, Cho YK, Jeong MH, Cho JG, Park JC, Kang JC, Ahn Y (2012) Curcumin reduces the cardiac ischemia-reperfusion injury: involvement of the toll-like receptor 2 in cardiomyocytes. The Journal of nutritional biochemistry 23 (11):1514-1523

59. Yu W, Wu J, Cai F, Xiang J, Zha W, Fan D, Guo S, Ming Z, Liu C (2012) Curcumin alleviates diabetic cardiomyopathy in experimental diabetic rats. PloS one 7 (12):e52013

60. Sunagawa Y, Sono S, Katanasaka Y, Funamoto M, Hirano S, Miyazaki Y, Hojo Y, Suzuki H, Morimoto E, Marui A (2014) Optimal dose-setting study of curcumin for improvement of left ventricular systolic function after myocardial infarction in rats. Journal of pharmacological sciences 126 (4):329-336

61. Pang X-F, Zhang L-H, Bai F, Wang N-P, Garner RE, McKallip RJ, Zhao Z-Q (2015) Attenuation of myocardial fibrosis with curcumin is mediated by modulating expression of angiotensin II AT1/AT2 receptors and ACE2 in rats. Drug design, development and therapy 9:6043

62. Allen S, Liu YG, Scott E (2016) Engineering Nanomaterials to Address Cell-Mediated Inflammation in Atherosclerosis. Regen Eng Transl Med 2 (1):37-50. doi:10.1007/s40883-016-0012-9

63. Liu R, Zhang H, Yang J, Wang J, Liu J, Li C (2018) Curcumin alleviates isoproterenol-induced cardiac hypertrophy and fibrosis through inhibition of autophagy and activation of mTOR. European review for medical and pharmacological sciences 22 (21):7500-7508

64. Liu W, Zhai Y, Heng X, Che FY, Chen W, Sun D, Zhai G (2016) Oral bioavailability of curcumin: problems and advancements. Journal of drug targeting 24 (8):694-702 
This is a post-peer-review, pre-copyedit version of an article published in Heart Failure Reviews. The final authenticated version is available online at: https://doi.org/10.1007/s10741-019-09854-6.

65. Ozawa H, Imaizumi A, Sumi Y, Hashimoto T, Kanai M, Makino Y, Tsuda T, Takahashi N, Kakeya H (2017) Curcumin $\beta$-D-glucuronide plays an important role to keep high levels of free-form curcumin in the blood. Biological and Pharmaceutical Bulletin 40 (9):1515-1524

66. Schiborr C, Eckert GP, Rimbach G, Frank J (2010) A validated method for the quantification of curcumin in plasma and brain tissue by fast narrow-bore high-performance liquid chromatography with fluorescence detection. Analytical and bioanalytical chemistry 397 (5):1917-1925

67. Feng T, Wei Y, Lee RJ, Zhao L (2017) Liposomal curcumin and its application in cancer. International journal of nanomedicine 12:6027

68. Tsuda T (2018) Curcumin as a functional food-derived factor: degradation products, metabolites, bioactivity, and future perspectives. Food \& function 9 (2):705-714

69. Mirzaei H, Shakeri A, Rashidi B, Jalili A, Banikazemi Z, Sahebkar A (2017) Phytosomal curcumin: a review of pharmacokinetic, experimental and clinical studies. Biomedicine \& Pharmacotherapy 85:102-112

70. Wang Y, Zhou S, Sun W, McClung K, Pan Y, Liang G, Tan Y, Zhao Y, Liu Q, Sun J (2014) Inhibition of JNK by novel curcumin analog C66 prevents diabetic cardiomyopathy with a preservation of cardiac metallothionein expression. American Journal of Physiology-Endocrinology and Metabolism 306 (11):E1239-E1247

71. Li C, Miao X, Lou Y, Lu Z, Adhikari BK, Wang Y, Liu Q, Sun J, Wang Y (2018) Cardioprotective effects of the novel curcumin analogue C66 in diabetic mice is dependent on JNK 2 inactivation. Journal of cellular and molecular medicine 22 (12):6314-6326

72. Bugyei-Twum A, Abadeh A, Thai K, Zhang Y, Mitchell M, Kabir G, Connelly KA (2016) Suppression of NLRP3 inflammasome activation ameliorates chronic kidney disease-induced cardiac fibrosis and diastolic dysfunction. Scientific reports 6:39551

73. Sunagawa Y, Morimoto T, Wada H, Takaya T, Katanasaka Y, Kawamura T, Yanagi S, Marui A, Sakata R, Shimatsu A (2011) A natural p300-specific histone acetyltransferase inhibitor, curcumin, in addition to angiotensinconverting enzyme inhibitor, exerts beneficial effects on left ventricular systolic function after myocardial infarction in rats. Circulation Journal:1107011292-1107011292

74. Ma J, Ma S-y, Ding C-h (2017) Curcumin reduces cardiac fibrosis by inhibiting myofibroblast differentiation and decreasing transforming growth factor $\beta 1$ and matrix metalloproteinase 9/tissue inhibitor of metalloproteinase 1. Chinese journal of integrative medicine 23 (5):362-369 
This is a post-peer-review, pre-copyedit version of an article published in Heart Failure Reviews. The final authenticated version is available online at: https://doi.org/10.1007/s10741-019-09854-6.

\section{Tables}

Table 1: A summary of studies evaluating curcumin's effects on cardiac fibrosis.

\begin{tabular}{|c|c|c|c|c|}
\hline Reference & $\begin{array}{c}\text { Animal/cell } \\
\text { type }\end{array}$ & $\begin{array}{c}\text { Cardiac fibrosis } \\
\text { condition induced by }\end{array}$ & $\begin{array}{c}\text { Curcumin } \\
\text { concentration(s)/treatment } \\
\text { duration }\end{array}$ & Outcomes \\
\hline Tang et al. [50] & $\begin{array}{l}\text { New Zealand } \\
\text { rabbits }\end{array}$ & $\begin{array}{l}\text { Combined aortic } \\
\text { regurgitation and aortic } \\
\text { stenosis }\end{array}$ & $\begin{array}{l}-100 \mathrm{mg} / \mathrm{kg} / \text { day } \\
-2 \text { months }\end{array}$ & $\begin{array}{l}\text {-Upregulation of } \\
\text { MMP-2 } \\
\text { - Upregulation of } \\
\text { MMP-9 } \\
\text {-Reduction of } \\
\text { collagen } \\
\text { deposition }\end{array}$ \\
\hline $\begin{array}{l}\text { Sunagawa et } \\
\text { al. [73] }\end{array}$ & $\begin{array}{l}\text { Sprague-Dawley } \\
\text { (SD) rats }\end{array}$ & $\begin{array}{l}\text { Myocardial infarction } \\
\text { (MI) }\end{array}$ & $\begin{array}{l}-50 \mathrm{mg} / \mathrm{kg} / \mathrm{day} \text { (combined } \\
\text { with/without enalapril) } \\
-6 \text { weeks }\end{array}$ & $\begin{array}{l}\text {-Decreased } \\
\text { perivascular } \\
\text { fibrosis expansion } \\
\text {-Additive effect } \\
\text { on fibrosis extent } \\
\text { when combined } \\
\text { with enalapril } \\
\text {-Repressed } \\
\text { expression of } \\
\text { p300 } \\
\text { transcriptional } \\
\text { coactivator } \\
\text { observed only in } \\
\text { animals subjected } \\
\text { to enalapril+Cur }\end{array}$ \\
\hline $\begin{array}{l}\text { Nakayama et } \\
\text { al. [51] }\end{array}$ & $\begin{array}{l}\text { Human liver- } \\
\text { derived HepG2 } \\
\text { cells }\end{array}$ & TGF- $\beta$ administration & $\begin{array}{l}-10 \mu \mathrm{mol} / 1 \\
-30 \mathrm{~min}\end{array}$ & $\begin{array}{l}\text {-Blunted PAI-1 } \\
\text { protein level }\end{array}$ \\
\hline $\begin{array}{l}\text { Soetikno et al. } \\
\text { [54] }\end{array}$ & SD rats & $\begin{array}{l}\text {-High glucose (HG) } \\
\text {-Streptozotocin (STZ) } \\
\text { injection } \\
\text { (diabetes induction) }\end{array}$ & $\begin{array}{l}-100 \mathrm{mg} / \mathrm{kg} / \mathrm{day} \\
-8 \text { weeks }\end{array}$ & $\begin{array}{l}\text { - PKC- } \alpha \\
\text { inactivation } \\
\text {-PKC- } \beta 2 \\
\text { inactivation } \\
\text {-Phosphorylation } \\
\text { diminution of } \\
\text { p38MAPK and } \\
\text { ERK1/2 } \\
\text {-Downregulation } \\
\text { of TGF- } \beta \text {, } \\
\text { osteopontin and } \\
\text { p300 } \\
\text {-Attenuated ECM } \\
\text { accumulation }\end{array}$ \\
\hline Kim et al. [58] & SD rats & $\begin{array}{l}\text { Ischemia/reperfusion } \\
\text { (I/R) injury }\end{array}$ & $\begin{array}{l}-300 \mathrm{mg} / \mathrm{kg} / \text { day } \\
-1 \text { week }\end{array}$ & $\begin{array}{l}\text { - Reduced TLR2 } \\
\text { expression } \\
\text { - Lowered } \\
\text { macrophage } \\
\text { infiltration } \\
\text { (CD68) and high }\end{array}$ \\
\hline
\end{tabular}


This is a post-peer-review, pre-copyedit version of an article published in Heart Failure Reviews. The final authenticated version is available online at: https://doi.org/10.1007/s10741-019-09854-6.

\begin{tabular}{|c|c|c|c|c|}
\hline & & & & $\begin{array}{l}\text { mobility group } \\
\text { box } 1\end{array}$ \\
\hline & $\begin{array}{l}\text { Neonatal rat- } \\
\text { derived } \\
\text { myocardial cells }\end{array}$ & $\begin{array}{l}\text {-Tumor necrosis factor } \\
\text { (TNF)- } \alpha \\
\text {-Peptidoglycan (PGN) } \\
- \\
\text { Hypoxia/reoxygenation } \\
\text { (H/R) }\end{array}$ & $\begin{array}{l}-10 \mu \mathrm{M} \\
-18 \text { hours }\end{array}$ & $\begin{array}{l}\text { - Reduced TLR2 } \\
\text { expression } \\
\text {-Reduced } \\
\text { monocyte } \\
\text { chemoattractant } \\
\text { protein (MCP)-1 }\end{array}$ \\
\hline Yu et al. [59] & Wistar rats & $\begin{array}{l}\text {-High fat diet (HFD) } \\
\text { - STZ injection }\end{array}$ & $\begin{array}{l}-100 \text { or } 200 \mathrm{mg} / \mathrm{kg} / \mathrm{day} \\
-4 \text { months }\end{array}$ & $\begin{array}{l}\text {-Limiting the } \\
\text { fibrosis area } \\
\text { - Increased } \\
\text { phosphorylated } \\
\text { protein kinase B } \\
\text { (Akt) and GSK- } \\
3 \beta\end{array}$ \\
\hline $\begin{array}{l}\text { Meng et al. } \\
\text { [13] }\end{array}$ & $\begin{array}{l}\text { Spontaneously } \\
\text { hypertensive } \\
\text { rats (SHRs) }\end{array}$ & Hypertension & $\begin{array}{l}-100 \mathrm{mg} / \mathrm{kg} / \mathrm{day} \\
-12 \text { weeks }\end{array}$ & 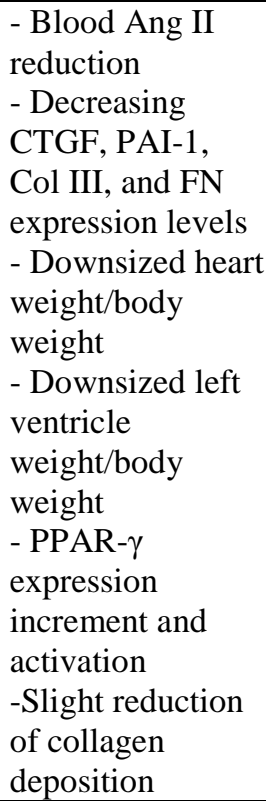 \\
\hline & $\begin{array}{l}\text { Cardiac } \\
\text { fibroblasts (CFs) }\end{array}$ & Ang II & $\begin{array}{l}-5,10,20 \mu \mathrm{mol} / \mathrm{L} \\
-1 \text { hour }\end{array}$ & $\begin{array}{l}\text { - Downregulation } \\
\text { of CTGF, PAI-1, } \\
\text { collagen type III, } \\
\text { FN, TGF- } \beta 1 \\
\text {-Decreased levels } \\
\text { of phosphorylated } \\
\text { Smad2/3 } \\
\text { - Promoted } \\
\text { PPAR- } \gamma \\
\text { expression and } \\
\text { binding capability } \\
\text {-Inhibition of CF } \\
\text { proliferation }\end{array}$ \\
\hline $\begin{array}{l}\text { Sunagawa et } \\
\text { al. [60] }\end{array}$ & SD rats & $\begin{array}{l}\text { Left coronary artery } \\
\text { ligation }\end{array}$ & $\begin{array}{l}-0.5,5 \text {, and } 50 \mathrm{mg} / \mathrm{kg} / \mathrm{day} \\
-24 \text { days }\end{array}$ & $\begin{array}{l}\text { - Concentration- } \\
\text { dependent } \\
\text { limitation of } \\
\text { fibrosis area }\end{array}$ \\
\hline $\begin{array}{l}\text { Bugyei-Twum } \\
\text { et al.[56] }\end{array}$ & $\begin{array}{l}\text { Rat H9c2 } \\
\text { myoblasts }\end{array}$ & $\begin{array}{l}\text { - high glucose (HG) } \\
\text { - TGF- } \beta 1\end{array}$ & $-25 \mu \mathrm{M}$ & $\begin{array}{l}\text {-Suppression of } \\
\text { p300 activity }\end{array}$ \\
\hline
\end{tabular}


This is a post-peer-review, pre-copyedit version of an article published in Heart Failure Reviews. The final authenticated version is available online at: https://doi.org/10.1007/s10741-019-09854-6.

\begin{tabular}{|c|c|c|c|c|}
\hline & & & & $\begin{array}{l}\text {-Reduction of } \\
\text { Smad acetylation } \\
\text {-Smad7 reduction } \\
\text { - Mitigated } \\
\text { collagen } \\
\text { production }\end{array}$ \\
\hline & $\begin{array}{l}\text { homozygous } \\
\text { TGR (mRen-2) } \\
27 \text { rats }\end{array}$ & $\begin{array}{l}\text {-Tail vein injection of } \\
\text { STZ }\end{array}$ & $-2 \%$ & $\begin{array}{l}\text { - Smad7 down- } \\
\text { regulation } \\
\text {-Attenuated ECM } \\
\text { synthesis } \\
\text {-Alleviated } \\
\text { cardiac } \\
\text { hypertrophy } \\
\text {-Restoration of } \\
\text { diastolic function }\end{array}$ \\
\hline $\begin{array}{l}\text { Chung et al. } \\
\text { [57] }\end{array}$ & $\begin{array}{l}\text { SD rat- isolated } \\
\text { cardiac } \\
\text { fibroblasts }\end{array}$ & $\begin{array}{l}\text { - Ang II } \\
\text { - TGF- } \beta 1\end{array}$ & $\begin{array}{l}-25 \mu \mathrm{M} \\
-1 \text { day }\end{array}$ & $\begin{array}{l}\text {-Elevated matrix } \\
\text { metalloproteinase } \\
\text { (MMP)-2 activity } \\
\text {-Reduction of } \\
\text { ERK1/2 } \\
\text { phosphorylation } \\
\text { level } \\
\text {-Diminished } \\
\text { levels of } \\
\text { phosphorylated } \\
\text { Smad2/3 and Akt } \\
\text { - Decrement of } \\
\text { CF proliferation } \\
\text { and migration } \\
\text {-Base line-level } \\
\text { production of } \\
\text { collagen }\end{array}$ \\
\hline Pang et al. [61] & SD rats & - Ang II & $\begin{array}{l}-150 \mathrm{mg} / \mathrm{kg} / \mathrm{day} \\
-2 \text {, and } 4 \text { weeks }\end{array}$ & $\begin{array}{l}\text { - AT1 receptor } \\
\text { suppression } \\
\text { - AT2 receptor } \\
\text { amplification } \\
\text {-Lowered } \\
\text { numbers of } \\
\text { macrophages and } \\
\text { myo-fibroblasts } \\
\text { expressing } \alpha \text { - } \\
\text { SMA } \\
\text {-TGF- } \beta 1 \text { down- } \\
\text { regulation } \\
\text { - Smad2/3 } \\
\text { phosphorylation } \\
\text { suppression } \\
\text { - Collagen I } \\
\text { production } \\
\text { diminution } \\
\text { - ACE2 } \\
\text { expression } \\
\text { augmentation }\end{array}$ \\
\hline Zeng et al. [53] & C57BL/6 mice & - HFD & $\begin{array}{l}\text { - } 50 \mathrm{mg} / \mathrm{kg} / \text { day } \\
\text { - } 8 \text { weeks }\end{array}$ & $\begin{array}{l}\text {-Diminished } \\
\text { collagen } \\
\text { deposition }\end{array}$ \\
\hline
\end{tabular}


This is a post-peer-review, pre-copyedit version of an article published in Heart Failure Reviews. The final authenticated version is available online at: https://doi.org/10.1007/s10741-019-09854-6.

\begin{tabular}{|c|c|c|c|c|}
\hline & & & & $\begin{array}{l}\text { - Decreased } \\
\text { expression level } \\
\text { of TGF- } \beta \text { and } \\
\text { CTGF } \\
\text {-Downregulation } \\
\text { of MMP-9 } \\
\text {-Diminished } \\
\text { collagen I } \\
\text { production }\end{array}$ \\
\hline & $\begin{array}{l}\text { H9c2 embryonic } \\
\text { myoblasts }\end{array}$ & - Palmitate (PA) & $\begin{array}{l}-20 \mu \mathrm{M} \\
-1 \text { hour }\end{array}$ & $\begin{array}{l}\text {-Reversal of } \\
\text { induced cardiac } \\
\text { hypertrophy } \\
\text { - TGF- } \beta \text { down- } \\
\text { regulation }\end{array}$ \\
\hline Liu et al. [62] & C57BL/6J mice & $\begin{array}{l}\text {-Ligation of left } \\
\text { femoral artery, great } \\
\text { saphenous artery, iliac } \\
\text { circumflex artery/vein, } \\
\text { and muscular branch } \\
\text { (left hindlimb } \\
\text { ischemia) }\end{array}$ & $\begin{array}{l}\text { - } 100 \mathrm{mg} / \mathrm{kg} \\
\text {-Administered1 hour before } \\
\text { the ligating surgery by } \\
\text { intraperitoneal (I.P.) } \\
\text { injection }\end{array}$ & $\begin{array}{l}\text { - Recovery of } \\
\text { cardiac fibrosis } \\
\text { injured areas } \\
\text { - Restricting NF- } \\
\text { kB activation } \\
\text {-Inhibiting } \\
\text { macrophage } \\
\text { infiltration } \\
\text {-Decreased } \\
\text { expression levels } \\
\text { of TNF- } \alpha \text {, IL-1, } \\
\text { and IL-6 }\end{array}$ \\
\hline Liu et al. [52] & $\begin{array}{l}\text { CFs derived } \\
\text { from neonatal } \\
\text { SD rats }\end{array}$ & - TGF- $\beta 1$ & $\begin{array}{l}-20 \mu \mathrm{mol} / 1 \\
-30 \mathrm{~min}\end{array}$ & $\begin{array}{l}\text {-Diminution of } \alpha \text { - } \\
\text { SMA and Col I } \\
\text { expression } \\
\text { - Reduced } \\
\text { activated forms of } \\
\text { Smad2 and p38 } \\
\text { MAPK }\end{array}$ \\
\hline Xiao et al. [8] & $\begin{array}{l}\text { C57BL/6J wild- } \\
\text { type mice }\end{array}$ & $\begin{array}{l}\text { - permanent left } \\
\text { anterior descending } \\
\text { coronary artery ligation } \\
\text { (MI induction) }\end{array}$ & $\begin{array}{l}-100 \mathrm{mg} / \mathrm{kg} / \mathrm{day} \\
-5 \text { weeks }\end{array}$ & $\begin{array}{l}\text {-Alleviation of } \\
\text { interstitial fibrosis } \\
\text {-Decreased levels } \\
\text { of collagen I, } \\
\text { collagen III, and } \\
\text { TGF- } \beta 1 \\
\text {-Restored SIRT1 } \\
\text { expression } \\
\end{array}$ \\
\hline & $\begin{array}{l}\text { CFs derived } \\
\text { from Wistar rats }\end{array}$ & - Ang II & $\begin{array}{l}-5,10 \text {, and } 15 \mu \mathrm{M} \\
-1 \text { hour }\end{array}$ & $\begin{array}{l}\text {-Repression of CF } \\
\text { proliferation and } \\
\text { migration } \\
\text {-MMP down- } \\
\text { regulation } \\
\text {-Increment in } \\
\text { SIRT1 expression } \\
\text { - Decreased levels } \\
\text { of collagen I, } \\
\text { collagen III, and } \\
\text { TGF- } \beta 1 \text { dose } \\
\text { dependently } \\
\text {-Decreased } \\
\text { expression of }\end{array}$ \\
\hline
\end{tabular}


This is a post-peer-review, pre-copyedit version of an article published in Heart Failure Reviews. The final authenticated version is available online at: https://doi.org/10.1007/s10741-019-09854-6.

\begin{tabular}{|c|c|c|c|c|}
\hline & & & & $\begin{array}{l}\text { MMP-9 and } \\
\text { MMP-2 }\end{array}$ \\
\hline \multirow[t]{2}{*}{ Ma et al. [74] } & SD rats & $\begin{array}{l}\text { - Isoproterenol (ISO) } \\
\text { injection }\end{array}$ & $\begin{array}{l}-150 \text { or } 300 \mathrm{mg} / \mathrm{kg} / \text { day } \\
-4 \text { weeks }\end{array}$ & $\begin{array}{l}\text { - Collagen I/III } \\
\text { level decrement in } \\
\text { myocardial } \\
\text { interstitium and } \\
\text { perivascular areas } \\
\text { - Suppression of } \\
\alpha \text {-SMA } \\
\text {-Reversal of } \\
\text { cardiac weight } \\
\text { index (CWI) } \\
\text { increment }\end{array}$ \\
\hline & $\begin{array}{l}3^{\text {rd }} \text { to } 5^{\text {th }} \\
\text { generations of } \\
\text { CFs isolated } \\
\text { from SD rats }\end{array}$ & - Ang II & $\begin{array}{l}-5,10, \text { and } 20 \mu \mathrm{mol} / \mathrm{L} \\
-1 \text { hour }\end{array}$ & $\begin{array}{l}\text { - Collagen I/III } \\
\text { reduction } \\
\text { - Fibroblast } \\
\text { proliferation and } \\
\text { differentiation } \\
\text { inhibition } \\
\text {-Expression } \\
\text { decrement } \\
\text { relating to TGF- } \\
\beta 1 \text {, matrix } \\
\text { metalloproteinase } \\
\text { (MMP)-9 and } \\
\text { tissue inhibitor of } \\
\text { metalloproteinase } \\
\text { (TIMP)-1 }\end{array}$ \\
\hline Fang et al. [12] & Human CFs & - TGF- $\beta 1$ & $\begin{array}{l}-20 \mu \mathrm{mol} / 1 \\
-1 \text { hour }\end{array}$ & $\begin{array}{l}\text {-Expression } \\
\text { reduction of: } \\
\alpha \text {-SMA, Col I, } \\
\text { Col III } \\
\text { - CF proliferation } \\
\text { repression } \\
\text {-Induction of } \\
\text { G2/M phase cell } \\
\text { cycle arrest } \\
\text { - Deactivation of } \\
\text { Smad2/3, p38 } \\
\text { MAPK, and ERK }\end{array}$ \\
\hline Liu et al. [63] & SD rats & -ISO & $\begin{array}{l}-200 \mathrm{mg} / \mathrm{kg} / \mathrm{day} \\
-4 \text { weeks }\end{array}$ & $\begin{array}{l}\text {-Decrement of } \\
\text { heart weight/body } \\
\text { weight } \\
\text { - Restoration of } \\
\text { ANP, } \alpha \text { - } \\
\text { MHC/MYH6, } \beta \text { - } \\
\text { MHC/MYH7 and } \\
\text { MYH7B } \\
\text { expression levels } \\
\text {-Shrinkage of } \\
\text { interstitial fibrosis } \\
\text { area } \\
\text { - Decrement in } \\
\text { procollagen I/III } \\
\text { production }\end{array}$ \\
\hline
\end{tabular}


This is a post-peer-review, pre-copyedit version of an article published in Heart Failure Reviews. The final authenticated version is available online at: https://doi.org/10.1007/s10741-019-09854-6.

\begin{tabular}{|c|c|c|c|c|}
\hline & & & & $\begin{array}{l}\text { - mTOR } \\
\text { expression } \\
\text { restoration } \\
\text {-Suppression of } \\
\text { LC3 and Belin-1 }\end{array}$ \\
\hline \multirow[t]{2}{*}{ Guo et al. [55] } & SD rats & $\begin{array}{l}\text { - High energy diet } \\
\text { - STZ injection }\end{array}$ & $\begin{array}{l}-300 \mathrm{mg} / \mathrm{kg} / \text { day } \\
-16 \text { weeks }\end{array}$ & $\begin{array}{l}\text {-Suppressed Col } \\
\text { I/III deposition } \\
\text { - Reduced TGF- } \\
\beta 1 \text {, T } \beta R \text { II and } \\
\text { phosphorylated } \\
\text { Smad 2/3 } \\
\text {-Smad } 7 \\
\text { amplification }\end{array}$ \\
\hline & Human CFs & - HG or TGF- $\beta 1$ & $-25 \mu \mathrm{mol} / \mathrm{L}$ & $\begin{array}{l}\text { - Moderation of } \\
\text { AMPK/p38 } \\
\text { MAPK activity } \\
\text {-Repression of } \\
\text { collagen } \\
\text { production }\end{array}$ \\
\hline
\end{tabular}


This is a post-peer-review, pre-copyedit version of an article published in Heart Failure Reviews. The final authenticated version is available online at: https://doi.org/10.1007/s10741-019-09854-6.

\section{Figure legends}

Figure 1. Epigenetic mechanisms in the formation of pro-fibrotic myofibroblasts. Following an injury or a stress, resident cardiac fibroblasts activate and differentiate into myofibroblasts. Myofibroblasts secrete extracellular matrix components (ECM), such as collagen, laminin, and fibronectin, and form fibrotic tissue. Epigenetics is a key player in this pro-fibrotic response, therefore it can be addressed for therapeutic purposes. Histone deacetylase (HDAC) inhibitors (mocetinostat, trichostatin A and MPT0E014 a pan HDAC inhibitor) have a direct action both on transforming growth factor beta (TGF- $\beta$ ) and cytokines including interleukin 6 (IL-6). Resveratrol activates Sirtuin 3 (SIRT-3) that indirectly blocks TGF-b/Smad3 pathway, thus suppressing fibroblast-to-myofibroblast transformation. Demethylating agents, such as 5-azacytidine can silence Ras association domain family 1 isoform A (RASSF1A), a tumor suppressor gene involved in fibroblast activation, and prevent cardiac fibrosis. Several cardiac microRNAs (miRNAs) have a cardio-protective activity by targeting the expression of TGF- $\beta$ and pro-fibrotic cytokines (miR133, miR30, miR15, and miR-378). Anti-miR-208 acts on the TGF- $\beta$ /Smad3 pathway. Anti-miR21 and anti-miR-19b can regulate TGF- $\beta 1$-mediated endothelial-to-mesenchymal transition via PTEN/Akt pathway. In endothelial cell, down-regulation of SET1 by HDAC inhibitors attenuates Ang II-induced cardiac fibrosis. Moreover, bone morphogenetic protein 7 (BMP7), an anti-fibrotic morphogen agent can reactivate Ras protein activator like 1 (RASAL1), thus reducing Ras-GTP activity and endothelial to mesenchymal transition (EndMT). With permission from [1]

Figure 2. Cur decreased collagen deposition in the left ventricles of SHRs. WKY rats were used as controls, and SHRs were treated with saline, Cur (100 mg· kg-1·d-1), or Cur (100 mg· kg-1·d1)+GW9662 (10 $\mathrm{mg} \cdot \mathrm{kg}-1 \cdot \mathrm{d}-1)$ by oral gavage for 12 weeks. Sirius Red staining was used to analyze the levels of collagen deposition in the left ventricles of WKY or SHRs ( $\mathrm{n}=8$ rats, each group). Scale bar: $100 \mu \mathrm{m}$. WKY: Wistar Kyoto rats; SHRs: spontaneously hypertensive rats. With permission from [13] 